EETP Vol. 16, 2021, №. 2(60)

ISSN 1896-2327 / e-ISSN 2353-7787

DOI: $10.35765 /$ eetp.2021.1660.03

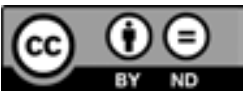

Nadesłano: 31.01 .2021

Zaakceptowano: 16.02.2021

Sugerowane cytowanie: Michniuk A. (2021). Kształcenie nauczycieli edukacji elementarnej w Islandii "Edukacja Elementarna w Teorii i Praktyce", vol. 16, nr 2(60), s 39-50.

DOI: $10.35765 /$ eetp.2021.1660.03

\author{
Anna Michniuk \\ ORCID: 0000-0002-5939-1371 \\ Akademia im. Jakuba z Paradyża w Gorzowie Wielkopolskim
}

\title{
Kształcenie nauczycieli edukacji elementarnej w Islandii
}

\section{Education of ECE (Early Childhood Education) Teachers in Iceland}

\section{SŁOWA KLUCZE ABSTRAKT}

nauczyciel, W artykule przedstawiono pokrótce specyfikę kraju, a także systemu

kształcenie oświaty, zwracając szczególną uwagę na edukację przedszkolną oraz nauczycieli, edukacja początkowy etap edukacji szkolnej (klasy 1-7). Celem artykułu jest elementarna, omówienie systemu kształcenia nauczycieli edukacji elementarnej Islandia w Islandii. Niniejsza charakterystyka została przygotowana głównie w oparciu o raporty Eurydice dostępne w Internecie, ofertę dwóch islandzkich szkół wyższych oraz obowiązujące w Islandii akty prawne. Jak pokazała przeprowadzona analiza, system kształcenia nauczycieli jest zbliżony do systemu obowiązującego w Polsce. By zostać nauczycielem edukacji elementarnej, należy ukończyć dwustopniowe studia pedagogiczne i zdobyć tytuł zawodowy magistra. Dokonując porównania między programami na studiach pedagogicznych prowadzonych w Polsce i w Islandii, należy zwrócić uwagę na fakt, że w przypadku Islandii większą wagę przywiązuje się do studenckich praktyk (szczególnie na Uniwersytecie w Akureyri) oraz do zajęć korespondujących z aktualnymi problemami, z którymi mierzy się świat w programach studiów pojawiają się przedmioty związane z tematyką równouprawnienia oraz gender, edukacją inkluzyjną, współpracą z rodzicami czy zarządzaniem klasą. 


\section{KEYWORDS ABSTRACT}

ECE (Early In the article, the author presents the specific characteristics of the Childhood country and its education system, especially pre-school and early Education), school education (grades 1 to 7 ). The aim of this article is to describe elementary the Icelandic system of training elementary education teachers. The education, Iceland, teacher, teacher description is mainly based on Eurydice reports which are available in training the internet, as well as on the academic offer of two Icelandic universities and the country's legal acts. The analysis shows that the Icelandic system of educating teachers is similar to the one in Poland: to become a teacher of elementary education, student has to complete two-stage pedagogical studies and obtain a master's degree. It should be noticed that during pedagogical studies in Iceland students' practice at schools is very important (especially at the University of Akureyri). Also, Icelandic universities focus on classes that are connected with various problems of the modern world (e.g., equality, gender, inclusive education, cooperation with parents, class management).

\section{Krótka charakterystyka kraju ognia i lodu}

Islandia to kraj położony na Oceanie Atlantyckim. Jego całkowita powierzchnia wynosi ok. 103000 km2. Rozmieszczanie ludności nie jest równomierne. Najwięcej osób mieszka w rejonie Reykjaviku oraz bliskich mu miastach: Kópavogur, Hafnarförður, Garðabær, Mosfellsbær. Większe miasteczka, usytuowane na wybrzeżach Islandii, to między innymi: Akureyri, Reykjanesbær, Árborg, Akranes oraz Fjarðabyggð. Centralną część wyspy stanowią tereny niezamieszkane (Machowski, Rzętała 2018).

$\mathrm{Na}$ Islandii żyje nieco ponad 360 tysięcy osób. Gęstość zaludnienia wynosi 3,2 osoby na $\mathrm{km}^{2}$. Co ciekawe, prawie $65 \%$ populacji mieszka w Reykjaviku, czyli stolicy Islandii. Do 1 grudnia 1918 roku Islandia należała do Danii, po tym czasie pozostała z Danią w unii. 17 czerwca 1944 roku została ogłoszona republiką. Dominującą religią Islandii jest luteranizm, czyli najstarszy nurt protestancki (por.: Eurydice 2018).

Przydomek kraju ognia i lodu Islandia otrzymała ze względu na występujące tam wulkany oraz lodowce. Część wulkanów nadal jest aktywna. Są to między innymi: Hekla, Katla, Askja, Grímsvötn oraz Hvannadalshnúkur, który jest jednocześnie najwyższym szczytem kraju. Aktywność wulkaniczną potwierdzają liczne gorące źródła oraz gejzery. Lodowce stanowią około $11 \%$ powierzchni kraju. Wśród nich wskazać możemy: Vatnajökull, Langjökull, Hofsjökull, Mýrdalsjökull oraz Drangajökull (por.: Fedorowicz 2018; Machowski, Rzętała 2018).

Ze względu na swoje specyficzne uwarunkowania geograficzne i geologiczne, Islandia jest krajem, którego gospodarka i funkcjonowanie bardzo mocno opierają się na 
dobrach naturalnych. Główną gałęzią gospodarki jest turystyka, a także usługi. Ważną część stanowi także rybołówstwo i przetwórstwo. Głównymi zasobami są energia geotermalna, energia wodna, a także aluminium (Węcławowicz 2018).

Islandczycy posługują się na co dzień językiem islandzkim, wielu z nich bardzo dobrze włada również językiem angielskim. W Islandii dużą grupę stanowią imigranci. Ponad 20 tys. osób pochodzi z Polski. Ze względu na fakt, że Polacy są tam coraz bardziej liczną mniejszością narodową, 3 marca 2020 roku polskie Ministerstwo Edukacji Narodowej wraz z islandzkim Ministerstwem Edukacji, Nauki i Kultury podpisało porozumienie o współpracy w dziedzinie oświaty, której pierwszym zadaniem było założenie polskiej szkoły przy Ambasadzie w Reykjaviku (MEN 2020).

\section{Miejsce edukacji elementarnej w islandzkim systemie oświaty}

Islandzki system oświaty zakłada, że obowiązek kształcenia dziecka zaczyna się w 6 . roku jego życia, a kończy w roku 16. Wyróżnić możemy 4 etapy: edukację przedszkolną, edukację obowiązkową (na którą składa się szkoła podstawowa oraz szkoła średnia pierwszego stopnia), edukację średnią drugiego stopnia oraz edukację wyższą. Finansuje go prawie w całości państwo. Szkoły prywatne nie są popularne.

Edukacja przedszkolna może trwać od narodzenia do szóstego roku życia. Nie jest obowiązkowa, mimo to prawie 95\% małych Islandczyków w wieku od 2 do 3 lat korzysta z przedszkola w swojej okolicy. Placówki, do których uczęszczają dzieci, nazywane są Leikskóli (ISCED 0). Pieczę nad przedszkolami pełnią Ministerstwo Edukacji, Nauki i Kultury (odpowiedzialne za program nauczania i politykę edukacyjna) oraz lokalne władze (zajmują się nadzorem i finansami). Każda placówka prowadzi zajęcia według własnych ram, należy jednak kierować się zasadą mówiącą o tym, że dziecko uczy się przez zabawę.

Islandzkie przedszkola prezentują holistyczne podejście do edukacji. Stawiają na równość, integrację, promowanie dobrego samopoczucia i uczenie się przez zabawę. Swoje działania opierają na sześciu filarach: alfabetyzacji, zrównoważonym rozwoju, zdrowiu i dobrobycie, demokracji i prawach człowieka, równości oraz kreatywności (Eurydice 2018/2019; The Preschool Act, No. 90, 12 June 2008).

W szóstym roku życia dziecko zaczyna swój obowiązek szkolny - rozpoczyna naukę w szkole podstawowej (od klasy pierwszej) i kontynuuje go do ukończenia szkoły średniej pierwszego stopnia (do klasy dziesiątej) (ISCED 1-2). Oba wskazane poziomy szkół zazwyczaj mieszczą się w tej samej placówce. Kształceniem specjalnym są objęte dzieci, dla których język islandzki nie jest językiem ojczystym, a także dzieci mające specjalne potrzeby edukacyjne (uczniowie niedowidzący, niesłyszący itp.). 
Jak już wspomniano, obowiązek szkolny w Islandii kończy się w 16. roku życia. Szkoła średnia drugiego stopnia jest dobrowolna. Edukacja w niej opiera się na podobnych filarach jak na etapach ją poprzedzających. Są to: umiejętność czytania i pisania (w najszerszym znaczeniu tego pojęcia), zdrowie i dobrobyt, demokracja i prawa człowieka, równość oraz kreatywność. Wśród islandzkich szkół średnich wyróżnić możemy, podobnie jak w Polsce, szkoły ogólnokształcące oraz zawodowe (Eurydice 2018/2019; Upper Secondary Education Act 2008 No 9212 June).

W Islandii działa obecnie siedem szkół wyższych. Cztery z nich są publiczne, trzy - prywatne. Do publicznych należą: Uniwersytet Rolniczy (Agricultural University of Iceland/Landbúnaðarháskóli Íslands), Uniwersytet w Hólar (Hólar University/ Háskólinn á Hólum), Uniwerstytet w Akureyri (University of Akureyri/Háskólinn á Akureyri) oraz Uniwersytet Islandzki w Reykjaviku (University of Iceland/Háskóli Íslands). W przypadku dwóch pierwszych szkół, studenci mogą kształcić się na kierunkach związanych z rolnictwem i przetwórstwem, a także turystyką. Pozostałe dwa uniwersytety oferują głównie kierunki bazujące na naukach humanistycznych, społecznych, a także medycznych.

Uczelnie prywatne działające na terenie Islandii to: 1) Uniwersytet Bifröst (Bifröst University/ Háskólinn á Bifröst) specjalizujący się w naukach prawnych, politycznych, biznesie i zarządzaniu (https://www.bifrost.is/english, dostęp: 21.01.2021); 2) Islandzka Akademia Sztuk Pięknych (Iceland University of the Arts/ Listaháskóli Íslands) w Reykjaviku, przygotowuje studentów w zakresie aktorstwa, tworzenia spektakli teatralnych, muzyki, mody, designu, architektury, a także eduakcji artystycznej (por. https://www.lhi.is/en [dostęp: 25.01.2021]; 3) Uniwersytet w Reykjaviku (Reykjavík University/Háskólinn í Reykjavík) prowadzi studia na dwóch wydziałach technologicznym oraz nauk społecznych, oferując studia z inżynierii stosowanej, prawa, psychologii czy biznesu (por. https://en.ru.is/ [dostęp: 25.01.2021]).

\section{Aspekty prawne zwiqzane z zatrudnieniem na stanowisku nauczyciela edukacji elementarnej w Islandii}

Zgodnie z obowiązującą od 1 stycznia 2020 roku Ustawą o kształceniu, kompetencjach i zatrudnianiu nauczycieli i dyrektorów szkół w przedszkolach, szkołach obowiązkowych i szkołach ponadgimnazjalnych nr 95 z dnia 1 lipca 2019 (Lög um menntun, hæfni og ráðningu kennara og skólastjórnenda við leikskóla, grunnskóla og framhaldsskóla 2019 nr. 95 1. Júlí), zatrudnienie w przedszkolach, szkole podstawowej lub średniej prowadzonej przez organ publiczny może uzyskać osoba, która posiada zawodowy tytuł nauczyciela i ukończyła pięcioletnie studia (w systemie bolońskim - trzyletnie studia licencjackie oraz dwuletnie studia magisterskie). Jeśli prawa do 
nauczania zostały nabyte w jednym z państw Europejskiego Obszaru Gospodarczego (EOG) lub na Wyspach Owczych, muszą zostać potwierdzone na wniosek zainteresowanego przez specjalną jednostkę Departamentu ds. Edukacji (Menntamálastofnun).

By zostać nauczycielem, należy wziąć udział w rekrutacji. Informacje o wolnych stanowiskach są jawne. Ogłoszenia publikowane są w lokalnych mediach, na stronach internetowych. Kandydaci muszą spełniać określone przez pracodawców wymagania, do których zaliczają się odpowiednie umiejętności, doświadczenie zawodowe, specjalizacja, a także wymagania edukacyjne (art. 13 ustawy). Co ważne, na stanowisku nauczyciela (podobnie jak w Polsce) nie może być zatrudniona osoba skazana. W czasie trwania rekrutacji możliwe jest pobranie wypisu z rejestru karnego i dokonanie weryfikacji kandydata.

Zgodnie z art. 14 przytoczonej ustawy, nauczyciele zatrudnieni w przedszkolach i szkołach podstawowych powinni stanowić $2 / 3$ pracującej kadry. Islandzkie prawo dopuszcza zatrudnianie nauczycieli, w wyjątkowych okolicznościach, bez konkursów. Dzieje się tak w przypadku urlopów macierzyńskich, chorób, urlopów przeznaczonych na naukę. Należy jednak pamiętać, że administracja szkoły stara się obsadzać wolne godziny pracownikami już zatrudnionymi, jednak, jeśli nie jest to możliwe, do współpracy zapraszani są inni dydaktycy, specjaliści, którzy nie muszą legitymować się licencją nauczycielską. Osoba na zastępstwo może być zatrudniona na mniej niż dwanaście miesięcy. Bez publikowania ogłoszenia o pracę dyrekcja może zatrudniać także na stanowiska nauczycielskie, które mają trwać do dwóch miesięcy, na mniej niż 1/3 etatu, a także w przypadku zatrudniania specjalistów, którzy mają prowadzić zajęcia w wymiarze mniejszym niż 240 minut w tygodniu (art. 18).

Według art. 19, jeśli żaden nauczyciel nie złoży swoich dokumentów w odpowiedzi na przygotowane i powtarzane ogłoszenie o pracę w przedszkolu, dyrekcja może tymczasowo zatrudnić osobę, która nie jest zawodowym nauczycielem. Zatrudnienie może trwać jednak tylko rok. Osoba taka nie będzie mogła być również zatrudniona na kolejny okres bez uprzedniego ogłoszenia. Decyzję o przyjęciu takiej osoby do pracy podejmuje samorząd terytorialny, lub w przypadku przedszkola prywatnego - właściciel.

Do pracy w szkołach podstawowych lub średnich dopuszcza się również osoby będące na studiach nauczycielskich, po potwierdzeniu postępów w nauce. Administracja placówki może zatrudnić studentów na nie więcej niż dwa lata. Pracownik nie będzie jednak nosił tytułu nauczyciela. Nie może też zostać zatrudniony po raz kolejny bez uprzedniego ogłoszenia. Każdy przypadek takiej formy zatrudnienia musi być zgłoszony do odpowiedniego wydziału ministerstwa - Departamentu ds. Edukacji (Menntamálastofnun).

Kompetencje, którymi powinni cechować się islandzcy nauczyciele, zostały dokładnie opisane w II rozdziale obowiązującej ustawy. Wśród nich wymieniono: 1) umiejętność tworzenia stymulującego środowiska uczenia się; 2) umiejętność oceny statusu 
i postępów ucznia; 3) umiejętność kierowania dobrostanem i edukacją uczniów w ich pracy oraz traktowania ich z szacunkiem i profesjonalizmem w sposób oparty na demokracji i równości; 4) umiejętność pracy na rzecz pozytywnej atmosfery w szkole i bezpiecznego środowiska szkolnego oraz promowania społecznej odpowiedzialności uczniów; 5) umiejętność promowania skutecznej i konstruktywnej współpracy na równych zasadach z domem i opiekunami uczniów; 6) umiejętność dzielenia się wiedzą w języku islandzkim; 7) umiejętność bycia profesjonalnym liderem, który dąży do stworzenia zorientowanej na reformy społeczności uczącej się i bierze odpowiedzialność za własny rozwój zawodowy i rozwija go w ciągu całego życia zawodowego.

\section{Przygotowanie do pracy w zawodzie nauczyciela edukacji elementarnej w Islandii}

Obecnie studia pedagogiczne prowadzone są na dwóch islandzkich uniwersytetach: na Uniwersytecie Islandzkim w Reykjaviku oraz na Uniwersytecie w Akureyri. Każda z wymienionych szkół wyższych prowadzi zajęcia dla osób, które chcą zostać nauczycielami i pracować z dziećmi. By zostać studentem na studiach pedagogicznych pierwszego stopnia (licencjackich), należy okazać zdany islandzki egzamin maturalny (Icelandic Stúdentspróf) lub inny równoważny dyplom. Wybierając studia pierwszego stopnia, kandydat musi zdecydować, czy będzie chciał pracować w przedszkolu, czy w szkole. W Islandii, ze względu na odmienny system edukacji, łączone studia z edukacji wczesnoszkolnej i przedszkolnej, takie, jak mamy w Polsce, nie miałyby sensu. Nauczyciele edukacji wczesnoszkolnej uczą dzieci do 7 klasy, a nie jak w Polsce - do 3. Ukończenie studiów pozwala ubiegać się o przyjęcie na studia magisterskie.

Uniwersytet Islandzki w Reykjaviku. Uniwersytet Islandzki (Háskóli Islands) został założony 17 czerwca 1911 roku. 1 lipca 2008 roku połączył się z Uniwersytetem Pedagogicznym, który obchodził 100-lecie istnienia. Od tamtego momentu funkcjonuje w nim 5 szkół: Szkoła Edukacji, Szkoła Inżynierii i Nauk Przyrodniczych, Szkoła Nauk o Zdrowiu, Szkoła Nauk Humanistycznych oraz Szkoła Nauk Społecznych (por. https://english.hi.is/university/history [dostęp: 20.01.2021]). Szkoła Edukacji (School of Education) prowadzi studia na wydziałach: 1) nauczania przedmiotowego, 2) promocji zdrowia, sportu oraz czasu wolnego, 3) edukacji i pedagogiki, 4) edukacji i różnorodności.

$\mathrm{Na}$ Wydziale Edukacji i Pedagogiki na poziomie studiów licencjackich znalazły się kierunki obejmujące: nauczanie w klasach podstawowych (Teaching in Primary Grades) oraz nauczanie w przedszkolu (Preschool Teacher Education). Wśród obowiązkowych przedmiotów realizowanych przez studentów na obu kierunkach wskazać można 
przedmioty związane z językiem i kulturą islandzką, psychologią rozwoju i uczenia się, komunikacją i przywództwem, muzyką, sztuką, literaturą, przedmiotami ścisłymi, badaniami pedagogicznymi, metodami prowadzenia zajęć. Oprócz tego, studenci mają również dostęp do szeregu przedmiotów fakultatywnych. Wśród nich wymienić można: gry i zabawy, zapobieganie przemocy rówieśniczej, psychologia pozytywna, nowe media, nauka o środowisku, nauczanie o elektryczności i magnetyzmie, gender, zarządzanie i projektowanie wydarzeń, projektowanie zabawek, design jako źródło kreatywności. Większość z nich jest bezpłatna. Wyjątek stanowią dwa przedmioty wymienione jako ostatnie - należą one do zajęć, za które trzeba uiścić dodatkową opłatę. Oferta przedmiotów do wyboru dla studentów kierunku nauczanie w klasach podstawowych jest bardziej rozbudowana i różnorodna ${ }^{1}$. Zarówno na kierunku nauczanie w klasach początkowych szkoły podstawowej, jak i nauczanie w przedszkolu, kształcenie prowadzone jest w języku islandzkim. Egzaminy i zaliczenia również odbywają się w języku islandzkim. Wybrane przedmioty prowadzone są w języku angielskim.

Uniwersytet $w$ Akureyri. Uniwersytet w Akureyri jest uczelnią publiczną założoną w 1987 roku. Na początku tworzyły ją dwa wydziały: nauk o zdrowiu oraz zarządzania przemysłowego. Co ciekawe, zajęcia dla studentów początkowo prowadzone były w dwóch salach na arenie sportowej w Akureyri. Naukę podjęło wtedy 31 studentów. Uczelnia zatrudniała na stałe czterech pracowników. Dość szybko szkoła zaczęła się jednak powiększać. Obecnie studenci mogą kształcić się w dziedzinach nauk społecznych, medioznawstwa, pielęgniarstwa, terapii zajęciowej, pedagogiki (nauczanie w przedszkolach i szkołach podstawowych), biotechnologii, prawa i policji, nauk współczesnych, psychologii, rybołówstwa, informatyki oraz administracji i biznesu na czterech wydziałach: Wydziale Edukacji, Wydziale Prawa, Wydziale Psychologii oraz Wydziale Nauk Społecznych (por. https://www.unak.is/english/university/about-unak/history [dostęp: 25.01.2021]).

Oferta skierowana dla przyszłych nauczycieli edukacji elementarnej, tj. nauczycieli edukacji przedszkolnej oraz wczesnoszkolnej, obejmuje 3-letnie studia licencjackie, po których można ubiegać się o przyjęcie na studia magisterskie z edukacji przedszkolnej lub wczesnoszkolnej, pedagogiki specjalnej oraz zarządzania oświatą. Studia, podobnie jak na Uniwersytecie Islandzkim, prowadzone są w języku islandzkim.

Studenci kształcący się na Uniwersytecie w Akureyri mają mniejszy wybór przedmiotów niż ci, którzy studiują na Uniwersytecie Islandzkim (być może wynika to

\footnotetext{
Szczegółowe programy dla obu kierunków studiów dostępne są na: https://ugla.hi.is/kennsluskra/index.php?tab=nam\&chapter=namsleid\&id=820238_20206\&kennsluar=2020 [dostęp: 11.01.2021] (nauczanie w klasach początkowych szkoły podstawowej [Teaching in Primary Grades]); https://ugla.hi.is/ kennsluskra/index.php?tab=nam\&chapter=namsleid\&id=520000_20206\&kennsluar=2020 [dostęp: 11.01.2021] (nauczanie w przedszkolu [Preschool Teacher Education]).
} 
z wielkości uczelni oraz dostępności specjalistów). W ramach edukacji przedszkolnej przyszli nauczyciele uczestniczą w obowiązkowych zajęciach z: języka islandzkiego, sztuki, historii i społeczeństwa, praktycznych umiejętności pedagogicznych, nauczania przedszkolnego, edukacji i pracy z technologią informacyjną, metodologii badań i statystyką, nauk ścisłych w nauce i zabawie, etyki, psychologii rozwojowej, rozwoju językowego i wspierania alfabetyzacji, planowania programu, współpracy z rodzicami, sztuki współczesnej, zabawy jako metody nauczania, edukacji środowiskowej, emisji głosu, zarządzania klasą i grupą. Oprócz tego, w programie studiów znalazły się dwa tygodnie praktyk na drugim roku studiów oraz dziesięć tygodni praktyk w ostatnim semestrze. Studenci w czasie studiów przygotowują prace licencjackie. Mają także tzw. przedmioty do wyboru. Wśród nich są: nauki ścisłe i nauczanie nauk ścisłych, muzyka i pedagogika muzyki, dziecko i społeczeństwo, sztuka wizualna i pedagogika sztuki wizualnej, literatura islandzka, komputery i sztuki wizualne, kreatywne pisanie, literatura dziecięca (por. https://ugla.unak.is/kennsluskra/index.php?tab=nam\&chapter= namsleid\&id=640014_20206\&kennsluar=2020 [dostęp: 25.01.2021].

W programie studiów dla nauczycieli mających pracować w szkołach podstawowych, zamiast przedmiotów korespondujących z pracą w przedszkolu, pojawiają się te, które będą pomocne w szkole. Wśród nich znalazły się: nauczyciel wczesnoszkolny, matematyka i nauczanie matematyki, język islandzki dla nauczycieli, dydaktyka, pierwsze kroki w nauce czytania, komunikacja, sztuka dyskusji i współpraca z rodzicami, język angielski. Przedmioty do wyboru, które nie pojawiły się w przypadku edukacji przedszkolnej, to: islandzki, zrównoważony rozwój i edukacja ekologiczna, nauczanie języków obcych (por. https://ugla.unak.is/kennsluskra/index.php?tab=nam\&chapter= namsleid\&id=640014_20206\&kennsluar=2020\&lina=402 [dostęp: 25.01.2021]).

$\mathrm{Na}$ studiach drugiego stopnia (magisterskich) przeznaczonych dla nauczycieli edukacji przedszkolnej, rozpoczętych w roku akademickim 2020/2021, należy zrealizować następujące przedmioty: metody nauczania i oceniania w przedszkolu, wdrażanie do nauki czytania i pisania, teoria uczenia się, edukacja włączająca, metody badań pedagogicznych, filozofia edukacji, rozwój zawodowy nauczyciela, przywództwo i zarządzanie klasą, najmłodsze dzieci (0-3) w przedszkolu, praktyki terenowe i nauczycielskie, seminarium magisterskie oraz dwa przedmioty do wyboru. Praktyki oraz seminarium są realizowane na drugim roku studiów. Nie ma już wtedy zajęć teoretycznych. (por. https://ugla.unak.is/kennsluskra/index.php?tab=nam\&chapter=nams leid\&id=640078_20206\&kennsluar=2020 [dostęp: 25.01.2021]).

W przypadku studiów drugiego stopnia dla nauczycieli mających pracować w szkołach podstawowych, sytuacja wygląda podobnie. Studenci na drugim roku realizują praktyki oraz przygotowują pracę magisterską, natomiast na pierwszym roku uczestniczą w zajęciach z: kształtowania umiejętności czytania i pisania, metod uczenia się i nauczania, edukacji włączającej, metod badań pedagogicznych, filozofii 
edukacji, gender, równości i demokracji, rozwoju zawodowego oraz przywództwa i zarządzania klasą. Ponadto studenci realizują także dwa przedmioty fakultatywne, które są dla nich obligatoryjne (por. https:/ugla.unak.is/kennsluskra/index.ph p? tab $=$ nam\&chapter $=$ namsleid $\& i d=640078 \_20206 \&$ kennsluar $=2020 \& l i n a=407$ [dostęp: 25.01.2021]).

\section{Doskonalenie zawodowe islandzkich nauczycieli}

Dorośli w Islandii mogą uczestniczyć w kursach i szkoleniach oferowanych przez władze publiczne, organizacje, firmy i instytucje prywatne. Największą popularnością wśród nauczycieli cieszą się jednak studia podyplomowe prowadzone w szkołach wyższych. Nauczyciele otrzymują na nie dofinansowanie, pokrywające czesne lub zakup niezbędnych podręczników. Istotnym motywatorem jest także możliwość zwiększenia wynagrodzenia. Należy jednak podkreślić, że dodatkowe studia nie są koniecznością. Nauczyciele sami decydują, czy chcą dalej się kształcić i utrzymać swoje umiejętności na wysokim poziomie.

W ofercie studiów podyplomowych Uniwersytetu Islandzkiego w Reykjaviku znalazły się m.in. następujące kierunki: edukacja dorosłych, przywództwo edukacyjne, mentoring i doradztwo edukacyjne, pomoc i opieka społeczna, edukacja włączająca (por. https://ugla.hi.is/kennsluskra/index.php?tab=nam\&kennsluar=2020\&flat urlisti=0\&namsstig=F\#svid40 [dostęp: 25.01.2021]).

Natomiast na Uniwersytecie w Akureyri znajdziemy studia np. z pedagogiki specjalnej, zarządzania i przywództwa, a także technologii informacyjnej (por. https:// ugla.unak.is/kennsluskra/index.php?tab=nam\&kennsluar=2020\&flaturlisti=1\&na msstig=F [dostęp: 25.01.2021]).

\section{Zakończenie}

Edukacja elementarna w Islandii funkcjonuje nieco inaczej niż w Polsce. Edukacja przedszkolna trwa w zasadzie od narodzenia do 6. roku życia (choć dopiero dzieci w wieku 2-3 lat uczęszczają do przedszkoli). Następnie dzieci przechodzą do obowiązkowej szkoły podstawowej, która jest połączona ze szkołą średnią I stopnia. Przez pierwsze siedem lat szkoły obowiązkowej dzieci rozwijają się pod okiem jednego nauczyciela (wyjątek stanowią sztuka i rzemieślnictwo oraz wychowanie fizyczne). Starsze dzieci, w klasach 8-10, nauczane są przez różnych nauczycieli, mając jednocześnie, podobnie jak w Polsce, wychowawcę - nauczyciela odpowiedzialnego za dany zespół klasowy. 
Ze względu na wskazaną odmienność systemu, w Islandii nie ma wspólnych studiów dla nauczycieli edukacji przedszkolnej i wczesnoszkolnej. Wyłącznie ukończenie pięciu lat studiów pozwala na uzyskanie pełnoprawnego tytułu nauczyciela. Dla porównania, w Polsce, by pracować w przedszkolu czy w edukacji wczesnoszkolnej, do niedawana wystarczyło mieć ukończone trzyletnie studia licencjackie. Od 2019 roku powrócono do pięcioletnich jednolitych studiów magisterskich z zakresu edukacji przedszkolnej oraz wczesnoszkolnej.

Po dokonaniu analizy islandzkich programów studiów dla przyszłych nauczycieli, należy zauważyć, że Uniwersytet w Akureyri jest bardzo mocno ukierunkowany na praktykę. W programie studiów zapisano do realizacji minimum 300 (!) godzin praktyk, które studenci muszą wykonać w przedszkolach i szkołach. Dla porównania obowiązujące w Polsce programy studiów dla nauczycieli przedszkolnych i wczesnoszkolnych zakładają konieczność realizacji 240 godzin praktyk. Ta różnica wskazuje, na czym skupia się polska szkoła - nie na umiejętnościach, ale na zapamiętywaniu rozbudowanych teorii, definicji, hierarchii czy systematyk.

Przyglądając się programom studiów, które są realizowane przez przyszłych islandzkich nauczycieli, można również zauważyć, że pojawia się w nich wiele przedmiotów związanych z problemami współczesnego świata (m.in. gender, ochrona środowiska, edukacja włączająca). Analizując obowiązujące w Islandii programy studiów oraz dokumenty prawne związane z edukacją, można wysnuć tezę, że Islandczycy dążą do wychowania i wykształcenia świadomego lokalnie i globalnie obywatela, otwartego na inność, w pełni gotowego do całożyciowego uczenia się, gotowego brać odpowiedzialność za swoje decyzje związane z edukacją i rozwojem.

\section{Bibliografia}

Fedorowicz, S. (2018). Islandzkie erupcje wulkaniczne w zapisie tefrochronologicznym paleogeografii Europy. [w:] L. Andrzejewski (red.), Przyrodnicze i spoteczne uwarunkowania wspótczesnych krajobrazów Islandii. Toruń: Wydawnictwo UMK, s. 61-66.

Machowski, R., Rzętała, M. (2018). Islandia-wyspa ognia, wody i lodu. [w:] R. Machowski (red.) Z badań nad wptywem antropopresji na środowisko, Sosnowiec: Wydział Nauk o Ziemi UŚ, s. 73-89.

Węcławowicz, G. (2018). System osadniczy, ludność i gospodarka Islandii. [w:] L. Andrzejewski (red.). Przyrodnicze i spoteczne uwarunkowania wspótczesnych krajobrazów Islandii. Toruń: Wydawnictwo UMK, s. 67-73. 


\section{Netografia}

Act on the education and recruitment of teachers and administrators of preschools, compulsory schools and upper secondary school 2008 No 8712 June; https://www. government.is/media/menntamalaraduneyti-media/media/frettatengt2016/Act-onthe-education-and-recruitment-of-teachers--No-87_2008-nr.-87-Uppfaerd-thydingjanuar-2017.pdf [dostęp: 24.01.2021].

Eurydice (2018/2019). https://eacea.ec.europa.eu/national-policies/eurydice/content/iceland_en [dostęp: 24.01.2021].

Historia Uniwersytetu w Akureyri: https://www.unak.is/english/university/about-unak/ history [dostęp: 24.01.2021].

Historia Uniwersytetu w Rejkjaviku: https:/english.hi.is/university/history [dostęp: 20.01.2021].

Islandzki Uniwersytet Artystyczny: https://www.lhi.is/en [dostęp: 24.01.2021].

Islandzki Uniwersytet Rolniczy: http://www.lbhi.is/school [dostęp: 24.01.2021].

Lög um menntun, hæfni og ráðningu kennara og skólastjórnenda við leikskóla, grunnskóla og framhaldsskóla 2019 nr. 95 1. Júlí, https://www.althingi.is/lagas/nuna/2019095. html [dostęp: 18.01.2021].

MEN (2020). https://www.gov.pl/web/edukacja-i-nauka/wspolpraca-polski-i-islandii-w-dziedzinie-oswiaty--deklaracja-podpisana [dostęp: 24.01.2021].

Oferta kierunków studiów dostępnych na Uniwersytecie Islandzkim: https://ugla.hi.is/ kennsluskra/index.php?tab $=$ nam \&kennsluar $=2020 \&$ flaturlisti $=0 \&$ namsstig=F\#sv id40 [dostęp: 20.01.2021].

Oferta kierunków studiów dostępnych na Uniwersytecie w Akureyri: https://ugla.unak.is/ kennsluskra/index.php?tab=nam\&kennsluar=2020\&flaturlisti $=1 \&$ namsstig=F $\quad$ [dostęp: 20.01.2021].

Program nauczania na studiach licencjackich z zakresu edukacji przedszkolnej (Uniwersytet Islandzki): https://ugla.hi.is/kennsluskra/index.php?tab=nam\&chapter=namsleid \&id=520000_20206\&kennsluar=2020 [dostęp: 11.01.2021].

Program nauczania na studiach licencjackich z zakresu nauczania w szkole podstawowej (Uniwersytet Islandzki): https://ugla.hi.is/kennsluskra/index.php?tab=nam\&chapter= namsleid\&id=820238_20206\&kennsluar=2020 [dostęp: 24.01.2021]

Program studiów licencjackich na kierunku pedagogicznym prowadzonym na Uniwersytecie w Akureyri: Uhttps://ugla.unak.is/kennsluskra/index.php?tab=nam\&chapter=na msleid\&id=640014_20206\&kennsluar=2020 [dostęp: 20.01.2021].

Program studiów magisterskich na kierunku pedagogicznym prowadzonym na Uniwersytecie w Akureyri: https://ugla.unak.is/kennsluskra/index.php?tab=nam\&chapter=nam sleid\&id=640078_20206\&kennsluar=2020 [dostęp: 24.01.2021].

The Preschool Act No. 90, 12 June 2008: https://www.government.is/media/menntamalaraduneyti-media/media/MRN-pdf_Annad/Preschool_Act.pdf [dostęp: 20.01.2021].

Uniwersytet Bifröst: https://www.bifrost.is/english, [dostęp: 24.01.2021].

Uniwersytet w Reykjaviku: https://en.ru.is/ [dostęp: 20.01.2021]. 
Upper Secondary Education Act 2008 No 9212 June: https://www.government.is/me$\mathrm{dia} /$ menntamalaraduneyti-media/media/law-and-regulations/Upper-Secondary-Education-Act-No.-92-2008.pdf [dostęp: 20.01.2021].

\section{ADRES DO KORESPONDENCJI}

\section{Anna Michniuk}

Akademia im. Jakuba z Paradyża w Gorzowie Wielkopolskim

e-mail: amichniuk@ajp.edu.pl 